\title{
Identification of nutritional descriptors of roasting intensity in beverages of Arabica and Robusta coffee beans
}

\author{
NATALINA CAVACO BICHO ${ }^{2}$, ANTÓNIO EDUARDO LEITÃO², JOSÉ COCHICHO \\ RAMALHO $^{2}$, NUNO BARTOLOMEU DE ALVARENGA ${ }^{3}$, \& FERNANDO CEBOLA LIDON ${ }^{1}$ \\ ${ }^{1}$ Departamento de Ciências e Tecnologia da Biomassa, Faculdade de Ciências e Tecnologia/Universidade Nova de Lisboa, Campus \\ da Caparica, 2829-516 Caparica, Portugal, ${ }^{2}$ Centro de Ecofisiologia, Bioquimica e Biotecnologia Vegetal/Instituto de Investigação \\ Cientifica Tropical, I.P., Quinta do Marquês, 2784-505 Oeiras, Portugal, and ${ }^{3}$ Departamento de Tecnologias e Ciências \\ Aplicadas, Instituto Politécnico de Beja, Rua Pedro Soares, 7800-295 Beja, Portugal
}

\begin{abstract}
Arabica and Robusta coffee beans were roasted at $220 \pm 10^{\circ} \mathrm{C}$ for 7,9 and 11 min to identify chemical descriptors in the beverages. The $\mathrm{pH}$ of the beverages showed the lowest value in the medium roasting level. In each degree of browning, the soluble solids content remained slightly higher in Arabica drinks. The contents of caffeine did not vary, but trigonelline decreased with burning up intensity. Chlorogenic acids also decreased with increasing roasting time. The 5-O-caffeoylquinic acid prevailed in Arabica and Robusta beverages, but the isomers of dicaffeoylquinic and feruolilquínic acids remained higher in Robusta. It was concluded that trigonelline and total caffeoylquinic, fatty dicaffeoylquinic and fatty feruolilquínic acids detached the beverages according to roasting intensity. Caffeine and $\mathrm{pH}$ allowed drinks separation between both species. Soluble solids take apart Arabica and Robusta drinks in each degree of roasting. All the individual groups of chlorogenic acids also explained $90 \%$ of the variance among samples.
\end{abstract}

Keywords: Arabica coffee, caffeine, chlorogenic acids, Robusta coffee, roasting intensity, trigonelline

\section{Introduction}

During a classic roasting, green coffee beans usually are subjected the temperature intervals $\left(180-190^{\circ} \mathrm{C}\right.$ and $220-230^{\circ} \mathrm{C}$ ) are related with the indicated temperatures 12 or 15 minutes (Correia 1995; Bicho 2005). Tissues structure of coffee beans starts changing at $50^{\circ} \mathrm{C}$ and with temperature elevation protein denaturation and water evaporation increase. Above $100^{\circ} \mathrm{C}$ beans undergo browning due to thermal decomposition and organic compounds pyrolysis. Gaseous substances, namely water vapour, carbon dioxide and carbon monoxide, are released and the bean volume increases at $150^{\circ} \mathrm{C}$. At $180-200^{\circ} \mathrm{C}$, with the disruption of the endosperm, caramelization starts, bean cracking occurs, bluish smoke appears and aroma develops (Blitz and Grocsh 1988). Thereafter, to prevent excessive browning and the loss of aroma, coffee beans are cooled with a stream of cold air or with water spray (Blitz and Grocsh 1988; Smith 1989).

Depending on roasting intensity and time of exposure, the chemical composition might change significantly in coffee beans and beverages (Correia 1995; Bicho 2005). The amount of caffeine, trigonelline and chlorogenic acids decreases during roasting (Nestlé 1991; Viani 1993; Bicho 2005, 2009). Trigonelline degradation further triggers nicotinic acid, pyridine, 3-methyl-pyridine and methyl ester of nicotinic acid synthesis (Bicho 2005, 2009). Roasting mediated the decrease of chlorogenic acids contents due to numerous reactions, such as isomerization, hydrolysis, oxidation, fragmentation, polymerization

Correspondence: Fernando Cebola Lidon, Departamento de Ciências e Tecnologia da Biomassa, Faculdade de Ciências e

Tecnologia/Universidade Nova de Lisboa, Campus da Caparica, 2829-516 Caparica, Portugal. Tel: + 00351212948543. E-mail: fj1@fct.unl.pt 
Table I. Levels of $\mathrm{pH}$, soluble solids, caffeine and trigonelline in beverages of Arabica and Robusta coffee beans roasted at $220 \pm 10^{\circ} \mathrm{C}$, for 7,9 and $11 \mathrm{~min}\left(T_{1}, T_{2}\right.$ and $\left.T_{3}\right)$, respectively.

\begin{tabular}{ccc}
\hline & Arabica & Robusta \\
\hline $\mathrm{pH}$ & $5.12 \pm 0.02^{\mathrm{ar}}$ & \\
$T_{1}$ & $4.98 \pm 0.01^{\mathrm{br}}$ & $5.27 \pm 0.02^{\mathrm{as}}$ \\
$T_{2}$ & $5.24 \pm 0.01^{\mathrm{as}}$ \\
$T_{3}$ & $5.47 \pm 0.03^{\mathrm{br}}$ \\
Soluble solids $\left(\mathrm{mg} \mathrm{cm}^{-3}\right)$ & \\
$T_{1}$ & $24.23 \pm 0.03^{\mathrm{cr}}$ & $23.88 \pm 0.22^{\mathrm{abr}}$ \\
$T_{2}$ & $21.50 \pm 0.95^{\mathrm{br}}$ & $20.17 \pm 0.94^{\mathrm{br}}$ \\
$T_{3}$ & $25.53 \pm 0.17^{\mathrm{ar}}$ & $23.21 \pm 0.94^{\mathrm{abr}}$ \\
Caffeine $\left(\mathrm{mg} \mathrm{cm}^{-3}\right)$ & \\
$T_{1}$ & $1.274 \pm 0.040^{\mathrm{ar}}$ & $2.163 \pm 0.057^{\text {as }}$ \\
$T_{2}$ & $1.127 \pm 0.109^{\mathrm{ar}}$ & $1.955 \pm 0.095^{\mathrm{as}}$ \\
$T_{3}$ & $1.330 \pm 0.008^{\mathrm{ar}}$ & $2.065 \pm 0.092^{\mathrm{as}}$ \\
Trigonelline $(\%)$ & \\
$T_{1}$ & $1.274 \pm 0.025^{\mathrm{ar}}$ & $0.912 \pm 0.017^{\text {as }}$ \\
$T_{2}$ & $1.107 \pm 0.034^{\mathrm{br}}$ & $0.790 \pm 0.034^{\mathrm{bs}}$ \\
$T_{3}$ & $0.566 \pm 0.007^{\mathrm{cr}}$ & $0.485 \pm 0.021^{\mathrm{cr}}$ \\
\hline
\end{tabular}

Notes: Each value is the mean $\pm \mathrm{SE}(n=3)$. Different letters indicate significant differences in a multiple range analysis, for $95 \%$ confidence level, among roasting for the same species ( $\mathrm{a}, \mathrm{b}$ and $\mathrm{c}$ ) or between coffee types for the same roasting ( $\mathrm{r}$ and $\mathrm{s}$ ).

and association of these compounds with denatured proteins (Clifford 1989). A large number of aromatic compounds, namely phenol esters, carbonyl compounds and esters, and polycyclic compounds also result due to thermal decomposition of chlorogenic acids (Clifford 1987). Hydroxycinnamic acids, especially chlorogenic acid in the double form of caffeine and potassium chlorogenate (Viani 1993; Clifford 1999), are significantly destroyed with the release of alkaloids (Correia 1990, 1995).

Following international standard regulations and considering the intensity of temperature and time of beans roasting, this work aims to identify, at a chemical level, descriptors in beverages of Arabica and Robusta coffees from Brazil and India.

\section{Materials and methods}

Sampling of Coffea arabica (from Brazil) and Coffea canephora (from India) was carried out according to Normativa Instrução $\mathrm{N}^{\circ} 8$ (2003), NP 1666 (1980) and ISO 4072 (1982), as recommended by International
Coffee Organization for sampling green coffee in bags. The sampling process began with the selection of green coffee bags (PSCB N ${ }^{\circ}$ 36/02 2002; Bicho et al. 2011), at random (a minimum of $10 \%$ of the lot). The selected bags were separated from the lot and $30 \pm 6 \mathrm{~g}$ of coffee was collected (in triplicate from the top, middle and bottom of the bag). After extraction and homogenization, the portions were mixed together, for an overall take of green coffee, with a minimum mass of $1.5 \mathrm{~kg}$ (Bicho et al. 2011). Arabica and Robusta green coffee samples were, therefore, roasted using the highest temperature $\left(220 \pm 10^{\circ} \mathrm{C}\right)$ applied in classical coffee burning and considering three browning times (7, 9 and $11 \mathrm{~min})$. These roasted samples were used for all the subsequent studies.

Following the criteria of Lingle (1996) and ABIC (2007), for the preparation of coffee drinks, samples of roasted beans were ground to a medium level. Coffee beverages were prepared according to ISO 6668 (1991) using coffee filters no. 4. Roasted ground coffee $(10 \pm 0.01 \mathrm{~g})$ was mixed with $100 \pm 0.01 \mathrm{ml}$ of mineral water and subjected to a temperature of $95-98^{\circ} \mathrm{C}$ for $4 \mathrm{~min}$. The process was performed in triplicate for each roasted coffee sample and the fractions were collected and mixed together to get a replicate for subsequent analysis. The above procedure was repeated to obtain triplicates of each drink.

Soluble solids and $\mathrm{pH}$ were measured according to AOAC (1996a,b). After calibration of the electrode with $\mathrm{pH} 4.0$ and 7.0 buffer solutions, $\mathrm{pH}$ was measured at $25^{\circ} \mathrm{C}$. For quantification of soluble solids, $25 \mathrm{ml}$ of the coffee drink was dried in a water bath until dryness and then placed in an oven at $105^{\circ} \mathrm{C}$. After cooling in a desiccator, the residue was weighted until the mass remained constant. Data are the average of triplicate for each sample of roasted coffee.

Caffeine and trigonelline contents were measured according to ISO 10095 (1992). Coffee drinks were prepared and cooled to room temperature. Samples were, therefore, water diluted 1:4(w/v), homogenized and filtered with a $0.45 \mu \mathrm{m}$ filter. Caffeine quantification was carried out in an integrated highperformance liquid chromatography system (Waters, equipped with UV-VIS detector, model 440, column Lichrosorb $100 \mathrm{RP}-18 /$ Merck, with $5 \mu \mathrm{m}$ in pore size, $4 \mu \mathrm{m}$ in diameter and $250 \mathrm{~mm}$ in length), using the

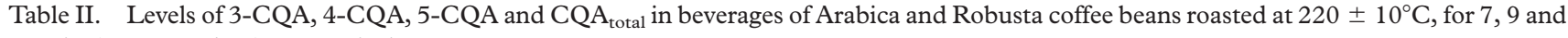
$11 \mathrm{~min}\left(T_{1}, T_{2}\right.$ and $\left.T_{3}\right)$, respectively.

\begin{tabular}{|c|c|c|c|c|c|}
\hline & & 3-CQA & 4-CQA & 5-CQA & $\mathrm{CQA}_{\text {total }}$ \\
\hline \multirow[t]{3}{*}{ Arabica $\left(\mathrm{mg} \mathrm{cm}^{-3}\right)$} & $T_{1}$ & $0.889 \pm 0.012^{\mathrm{ar}}$ & $1.092 \pm 0.017^{\mathrm{ar}}$ & $1.958 \pm 0.024^{\mathrm{ar}}$ & $3.939 \pm 0.052^{\mathrm{ar}}$ \\
\hline & $T_{2}$ & $0.503 \pm 0.015^{\mathrm{br}}$ & $0.676 \pm 0.022^{\mathrm{br}}$ & $1.053 \pm 0.036^{\mathrm{br}}$ & $2.232 \pm 0.073^{\mathrm{br}}$ \\
\hline & $T_{3}$ & $0.196 \pm 0.001^{\mathrm{cr}}$ & $0.247 \pm 0.001^{\mathrm{cr}}$ & $0.351 \pm 0.001^{\mathrm{cr}}$ & $0.794 \pm 0.002^{\mathrm{cr}}$ \\
\hline \multirow[t]{3}{*}{ Robusta $\left(\mathrm{mg} \mathrm{cm}^{-3}\right)$} & $T_{1}$ & $0.937 \pm 0.018^{\mathrm{ar}}$ & $1.147 \pm 0.024^{\mathrm{ar}}$ & $1.913 \pm 0.035^{\mathrm{ar}}$ & $3.997 \pm 0.077^{\mathrm{ar}}$ \\
\hline & $T_{2}$ & $0.577 \pm 0.013^{\mathrm{bs}}$ & $0.742 \pm 0.017^{\mathrm{br}}$ & $1.118 \pm 0.026^{\mathrm{br}}$ & $2.437 \pm 0.055^{\mathrm{br}}$ \\
\hline & $T_{3}$ & $0.251 \pm 0.002^{\mathrm{cr}}$ & $0.316 \pm 0.003^{\mathrm{cr}}$ & $0.410 \pm 0.030^{\text {cr }}$ & $1.004 \pm 0.009^{\mathrm{cr}}$ \\
\hline
\end{tabular}

Notes: Each value is the mean \pm SE $(n=3)$. Different letters indicate significant differences in a multiple range analysis, for $95 \%$ confidence level, among roasting for the same species $(\mathrm{a}, \mathrm{b}$ and $\mathrm{c}$ ) or between coffee types for the same roasting ( $\mathrm{r}$ and $\mathrm{s}$ ). 
Table III. Levels of 3,4-diCQA, 3,5-diCQA, 4,5-diCQA and diCQA total in beverages of Arabica and Robusta coffee beans roasted at $220 \pm 10^{\circ} \mathrm{C}$, for 7,9 and $11 \mathrm{~min}\left(T_{1}, T_{2}\right.$ and $\left.T_{3}\right)$, respectively.

\begin{tabular}{lccccr}
\hline & & $3,4-d i C Q A$ & $3,5-d i C Q A$ & $4,5-d i C Q A$ & diCQA total \\
\hline Arabica $\left(\mathrm{mg} \mathrm{cm}^{-3}\right)$ & $T_{1}$ & $0.100 \pm 0.001^{\mathrm{ar}}$ & $0.075 \pm 0.001^{\mathrm{ar}}$ & $0.099 \pm 0.001^{\mathrm{ar}}$ & $0.274 \pm 0.003^{\mathrm{ar}}$ \\
& $T_{2}$ & $0.038 \pm 0.001^{\mathrm{br}}$ & $0.026 \pm 0.001^{\mathrm{br}}$ & $0.029 \pm 0.002^{\mathrm{br}}$ & $0.093 \pm 0.004^{\mathrm{br}}$ \\
& $T_{3}$ & $0.008 \pm 0.000^{\mathrm{cr}}$ & $0.005 \pm 0.000^{\mathrm{cr}}$ & $0.004 \pm 0.000^{\mathrm{cr}}$ & $0.017 \pm 0.000^{\mathrm{cr}}$ \\
Robusta $\left(\mathrm{mg} \mathrm{cm}^{-3}\right)$ & $T_{1}$ & $0.181 \pm 0.020^{\mathrm{as}}$ & $0.134 \pm 0.004^{\mathrm{as}}$ & $0.134 \pm 0.006^{\mathrm{as}}$ & $0.479 \pm 0.011^{\text {as }}$ \\
& $T_{2}$ & $0.095 \pm 0.002^{\mathrm{bs}}$ & $0.058 \pm 0.001^{\mathrm{bs}}$ & $0.058 \pm 0.002^{\mathrm{bs}}$ & $0.219 \pm 0.005^{\mathrm{bs}}$ \\
& $T_{3}$ & $0.023 \pm 0.000^{\mathrm{cs}}$ & $0.013 \pm 0.000^{\mathrm{cs}}$ & $0.013 \pm 0.000^{\mathrm{cs}}$ & $0.050 \pm 0.001^{\mathrm{cs}}$
\end{tabular}

Notes: Each value is the mean \pm SE $(n=3)$. Different letters indicate significant differences in a multiple range analysis, for $95 \%$ confidence level, among roasting for the same species $(\mathrm{a}, \mathrm{b}$ and $\mathrm{c}$ ) or between coffee types for the same roasting ( $\mathrm{r}$ and $\mathrm{s}$ ).

32 Karat Software (version 7.0, build 1048, 1998 2003 Copyright Beckman Coulter, Inc.). The mobile

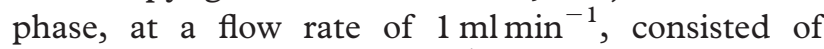
phosphate buffer $\left(0.02 \mathrm{moll}^{-1}\right.$ and acetonitrile, 9:1). The column temperature was maintained at $25^{\circ} \mathrm{C}$, a wavelength of $254 \mathrm{~nm}$ was applied and aliquots of $20 \mu \mathrm{l}$ were injected. A standard curve was constructed for caffeine using eight solutions with concentrations ranging between 7.813 and $1.000 \mathrm{~g} \mathrm{ml}^{-1}$. Seven solutions with concentrations ranging between 7.813 and $500 \mu \mathrm{g} \mathrm{ml}^{-1}$ were also used for the standard curve of trigonelline. Data were within the detection limits of the method. All extractions and chromatographic analysis were performed in triplicate.

Chlorogenic acids analysis followed Correia (1990). To $10 \mathrm{ml}$ of coffee drink, and $1 \mathrm{ml}$ of Carrez solution II (aqueous solution of zinc acetate dihydrate and glacial acetic acid, $10.95 \mathrm{~g}$ and $1.5 \mathrm{ml}$, respectively, to a final volume of $50 \mathrm{ml}$ ) and Carrez solution II (aqueous solution of $5.3 \mathrm{~g}$ of potassium hexacyanoferrate II trihydrate in a final volume of $50 \mathrm{ml}$ ) were added for clarification and thereafter methanol:water (40:60) was added to a final volume of $100 \mathrm{ml}$. After $15 \mathrm{~min}$, the mixture was filtered through a Whatman filter no. 1 and an aliquot of $10 \mathrm{ml}$ was removed and filtered again with a $0.45 \mu \mathrm{m}$ filter. For quantification, an integrated high-performance liquid chromatography system (Beckman System Gold, equipped with diode array detector, model 168, and a reverse-phase column Spherisorb S5 ODS2/Waters, with $4.6 \mathrm{~mm}$ diameter and $250 \mathrm{~mm}$ in length) with a 32 Karat Software (version 7.0, build 1048, 1998-2003 Copyright Beckman Coulter, Inc.) was used. To the mobile phase, a gradient elution program was applied (solvent
A tripotassium citrate buffer solution $0.01 \mathrm{moll}^{-1}, \mathrm{pH}$ 2.5 and solvent $\mathrm{B}$ methanol $100 \%$, at a flow rate of $1 \mathrm{ml} \mathrm{min}{ }^{-1}$; starting $80 \%$ solvent A and $20 \%$ solvent B to a final of $30 \%$ solvent $\mathrm{A}$ and $70 \%$ solvent $\mathrm{B}$; each run $45 \mathrm{~min}$ ), detection was made at wavelengths of 325 and $330 \mathrm{~nm}$, and a sample volume of $20 \mu \mathrm{l}$ was injected.

For isomerization of chlorogenic acids, $200 \mathrm{mg}$ of 5 -caffeoylquinic acid was diluted in $20 \mathrm{ml}$ of distilled water and the $\mathrm{pH}$ was adjusted to 8 with ammonium hydroxide $\left(4 \mathrm{moll}^{-1}\right)$. The solution was boiled for $30 \mathrm{~min}$ in a water bath, cooled and then the $\mathrm{pH}$ was adjusted to 2.5 with $\mathrm{HCl}\left(4 \mathrm{moll}^{-1}\right)$. After filtration, the samples were used for quantification. The identification and quantification of chromatographic peaks was carried out using standard solutions of 5-Ocaffeoylquinic acid (5-CQA). To identify the isomers 3-O-caffeoylquinic acid (3-CQA) and 4-O-caffeoylquinic acid (4-CQA), the standard 5-CQA was subjected to isomerization as described. The peaks appeared in the following sequence: 3-CQA, 3-Oferuolilquínic acid (3-FQA), 4-CQA, 5-CQA, 4-Oferuolilquínic acid, 5-O-feruolilquínic acid (5-FQA), 3,4-O-dicaffeoylquinic acid (3,4-diCQA), 3,5-Odicaffeoylquinic acid (3,5-diCQA) and 4,5-Odicaffeoylquinic acid (4,5-diCQA). The calibration curve was obtained from 5-CQA with readings at 325 and $330 \mathrm{~nm}$. The quantification considered the peak areas and the standard 5-CQA. To quantify each compound, the following equation was used (Correia 1990; Farah et al. 2005): $c=$ $\left[\mathrm{Fr} \times \varepsilon_{1} \times \mathrm{Mr}_{2} \times A\right] /\left[\varepsilon_{2} \times \mathrm{Mr}_{1}\right]$ (where $c$ is the concentration of the isomer to be quantified, in $\mathrm{mgl}^{-1}$; Fr is the response factor of the standard 5-CQA,

Table IV. Levels of 3-FQA, 5-FQA and $\mathrm{FQA}_{\text {total }}$ in beverages of Arabica and Robusta coffee beans roasted at $220 \pm 10^{\circ} \mathrm{C}$, for 7, 9 and $11 \mathrm{~min}$ $\left(T_{1}, T_{2}\right.$ and $\left.T_{3}\right)$, respectively.

\begin{tabular}{lcccr}
\hline & & 3-FQA & 5-FQA & FQA $_{\text {total }}$ \\
\hline Arabica $\left(\mathrm{mg} \mathrm{cm}^{-3}\right)$ & $T_{1}$ & $0.061 \pm 0.001^{\text {ar }}$ & $0.133 \pm 0.003^{\text {ar }}$ & $0.194 \pm 0.005^{\text {ar }}$ \\
& $T_{2}$ & $0.045 \pm 0.002^{\text {br }}$ & $0.087 \pm 0.004^{\text {br }}$ & $0.132 \pm 0.006^{\text {br }}$ \\
Robusta $\left(\mathrm{mg} \mathrm{cm}^{-3}\right)$ & $T_{3}$ & $0.027 \pm 0.000^{\text {cr }}$ & $0.033 \pm 0.001^{\text {cr }}$ & $0.060 \pm 0.001^{\text {cr }}$ \\
& $T_{1}$ & $0.141 \pm 0.004^{\text {as }}$ & $0.324 \pm 0.009^{\text {as }}$ & $0.465 \pm 0.013^{\text {as }}$ \\
& $T_{2}$ & $0.095 \pm 0.003^{\text {bs }}$ & $0.175 \pm 0.008^{\text {bs }}$ & $0.270 \pm 0.011^{\text {bs }}$ \\
& $T_{3}$ & $0.060 \pm 0.000^{\text {cs }}$ & $0.097 \pm 0.001^{\text {cs }}$ & $0.158 \pm 0.001^{\text {cs }}$ \\
\hline
\end{tabular}

Notes: Each value is the mean \pm SE $(n=3)$. Different letters indicate significant differences in a multiple range analysis, for $95 \%$ confidence level, among roasting for the same species ( $\mathrm{a}, \mathrm{b}$ and $\mathrm{c}$ ) or between coffee types for the same roasting ( $\mathrm{r}$ and $\mathrm{s}$ ). 
Table V. Correlation coefficients between the first, second and third principal components $\left(\mathrm{CP}_{1}, \mathrm{CP}_{2}\right.$ and $\left.\mathrm{CP}_{3}\right)$ with 3-CQA, 4-CQA, 5-CQA, 3,4-diCQA, 3,5-diCQA, 4,5-diCQA, 3-FQA and 5-FQA.

\begin{tabular}{lccr}
\hline Variables & $\mathrm{CP}_{1}$ & $\mathrm{CP}_{2}$ & $\mathrm{CP}_{3}$ \\
\hline $\mathrm{pH}$ & 0.600 & 0.746 & -0.185 \\
Soluble solids & 0.191 & 0.106 & -0.970 \\
Caffeine & -0.099 & 0.932 & 0.211 \\
Trigonelline & -0.786 & -0.583 & -0.109 \\
$\mathrm{CQA}_{\text {total }}$ & -0.978 & 0.012 & -0.159 \\
diCQA $_{\text {total }}$ & -0.900 & 0.388 & -0.129 \\
FQA $_{\text {total }}$ & -0.769 & 0.616 & 0.053 \\
Eigenvalue & 3.38 & 2.31 & 1.08 \\
Variance (\%) & 48.28 & 32.96 & 15.37 \\
\hline
\end{tabular}

in $\mathrm{mg}^{-1}$ per unit area; $\varepsilon_{1}$ is the molar absorption coefficient of the standard 5-CQA, in $1 \mathrm{~mol}^{-1} \mathrm{~cm}^{-1}$; $\varepsilon_{2}$ is the molar absorption coefficient of the isomer to be quantified, in $1 \mathrm{~mol}^{-1} \mathrm{~cm}^{-1} ; \mathrm{Mr}_{2}$ is the molecular weight of the isomer under study caffeoylquinic acids $=354.31 \mathrm{~g} \mathrm{~mol}^{-1}$, fatty feruolilquínic acids $=368.28 \mathrm{~g} \mathrm{~mol}^{-1}$, fatty dicaffeoylquinic acids $=516.44 \mathrm{~g} \mathrm{~mol}^{-1} ; \mathrm{Mr}_{1}$ is the molar mass of acid 5-CQA; $A$ is the peak area of the isomer to be quantified). The molar absorption coefficients (3-CQA $=18,400,4-\mathrm{CQA}=18,000,5-\mathrm{CQA}=19,500$, 3,4 -diCQA $=31,800,3,5$-diCQA $=31,600,4,5-$ $\operatorname{diCQA}=33,200, \quad$ with $\lambda=330 \mathrm{~nm} ; \quad 3-\mathrm{FQA}$ $=19,000, \quad 4-O$-feruolilquínic $\quad$ acid $=19,500$, $5-\mathrm{FQA}=19,300$, with $\lambda=325 \mathrm{~nm}$ ) indicated by Correia (1990) and Farah et al. (2005), in $1 \mathrm{~mol}^{-1} \mathrm{~cm}^{-1}$, were used. Data were within the detection limits of the method. All extractions and chromatographic analysis were performed in triplicate.

Data were statistically analysed using a one-way ANOVA $(p \leq 0.05)$. On the basis of the ANOVA results, a Tukey's test was performed for mean comparison, for a $95 \%$ confidence level. Different letters indicate significant differences. Multivariate analysis was carried out with STATISTICA software Copyright StatSoft, Inc., following Neto and Moita (1998), Alvarenga (2009), Chapman et al. (2001), Maeztu et al. (2001) and Da Silva et al. (2004).

\section{Results and discussion}

The soluble solid contents ranging between about 20 and $26 \mathrm{mg} \mathrm{cm}^{-3}$ were slightly higher in Arabica beverages for the same degree of browning and showed the lowest value in the roasting at $220 \pm 10^{\circ} \mathrm{C}$, for $9 \mathrm{~min}$ (Table I). Accordingly, the soluble solid contents remained within reference values (Illy and Viani 1998; Maeztu et al. 2001). In Arabica and Robusta coffees, the $\mathrm{pH}$ of the beverages also showed the lowest value in the same roasting level and varied from 4.98 to 5.39 and from 5.24 to 5.47 , respectively (Table I). In this context, according to Clifford (1987), only the Arabica coffee beverage after beans roasting at
$220 \pm 10^{\circ} \mathrm{C}$ for $11 \mathrm{~min}$ was not be palatable, because $\mathrm{pH}$ must vary between 4.90 and 5.20 or from 5.00 to 5.80 in Arabica and Robusta coffees, respectively. Nevertheless, considering that Brazilian Arabica coffees have a low acidity (Mendonça et al. 2005), according to the criteria of Maeztu et al. (2001) and Fujioka and Shibamoto (2008), regardless of the intensity of roasting, all the coffee beverages can be considered within limits of acceptance because the $\mathrm{pH}$ varied between 4.8 and 6.0. Following also the assumptions of Clifford (1987), the quality of Arabica (but not Robusta) beans roasted at $220 \pm 10^{\circ} \mathrm{C}$ for $9 \mathrm{~min}$ further pointed to a gourmet rating. The caffeine contents varied between 1.2 and $2 \mathrm{mg} \mathrm{cm}^{-3}$ and were lower in Arabica coffee drinks, but did not vary significantly with the degree of roast (Table I). Nevertheless, these data were below the reference values 2.09 and $2.88 \mathrm{mg} \mathrm{cm}^{-3}$, as shown for Arabica and Robusta coffees by Maeztu et al. (2001), possibly because caffeine levels vary with the type of grinding

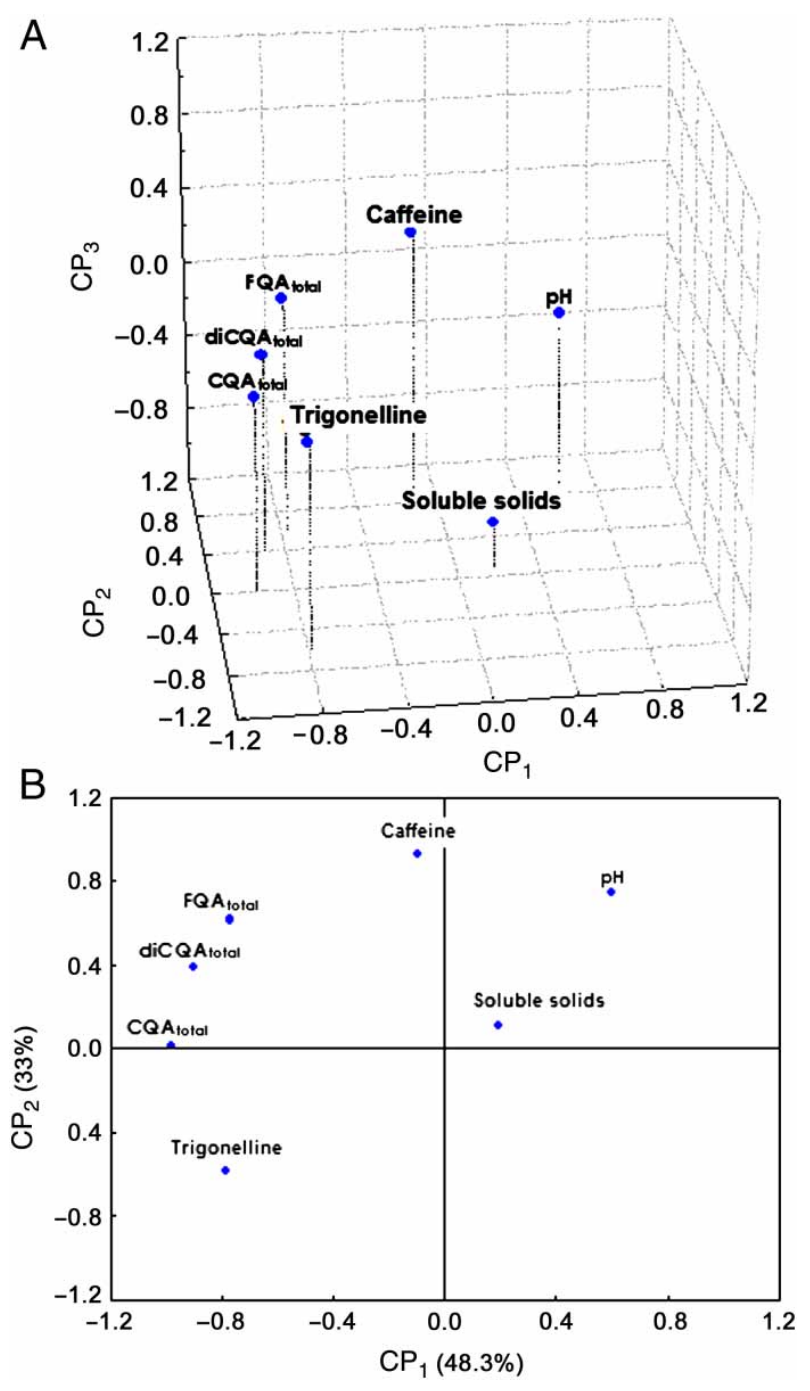

Figure 1. Projection of $\mathrm{pH}$, soluble solids, caffeine, trigonelline, $\mathrm{CQA}_{\text {total }}$, diCQA $\mathrm{A}_{\text {total }}$ and $\mathrm{FQA}_{\text {total }}$ in plans defined by (A) first, second and third components $\left(\mathrm{CP}_{1}, \mathrm{CP}_{2}\right.$ and $\left.\mathrm{CP}_{3}\right)$; (B) first and second components $\left(\mathrm{CP}_{1}\right.$ and $\left.\mathrm{CP}_{2}\right)$. 
A
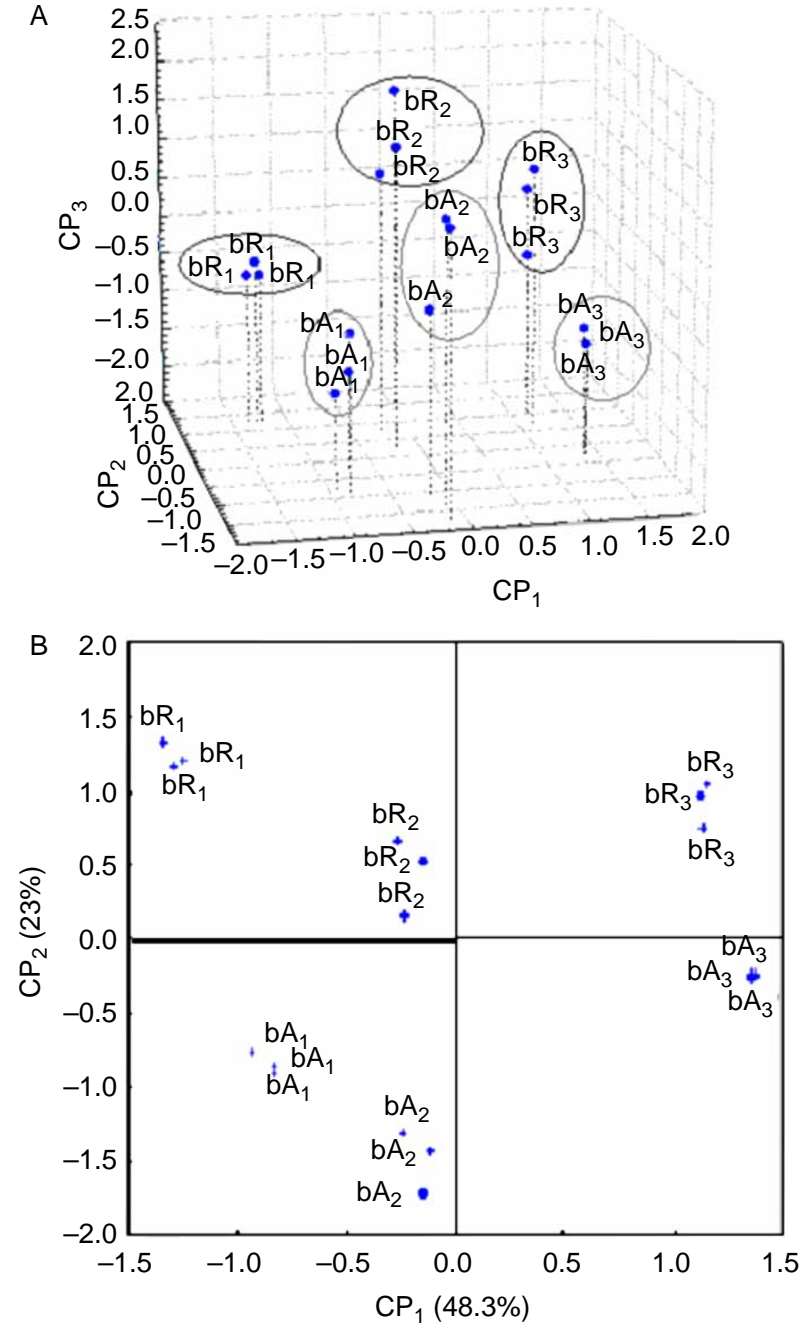

Figure 2. Projection of $\mathrm{pH}$, soluble solids, caffeine, trigonelline, $\operatorname{diCQA}_{\text {total }}$, diCQA $A_{\text {total }}$ and $F Q A_{\text {total }}$ in plans defined by (A) first, second and third components $\left(\mathrm{CP}_{1}, \mathrm{CP}_{2}\right.$ and $\left.\mathrm{CP}_{3}\right)$; (B) first and second components $\left(\mathrm{CP}_{1}\right.$ and $\left.\mathrm{CP}_{2}\right)$. The symbols have the following meaning: $b=$ beverage; $A_{1}, A_{2}, A_{3}$ and $R_{1}, R_{2}, R_{3}=$ roasting of Arabica and Robusta green beans at $220 \pm 10^{\circ} \mathrm{C}$, for 7,9 and $11 \mathrm{~min}$, respectively.

and brewing and with the ratio between water and coffee mass used for the preparation of the beverages (Bell et al. 1997; Andueza et al. 2003). In the coffee beverages, trigonelline content also diminished with increasing roasting intensity, but remained higher in Arabica drinks (Table I). Reference levels of 1.15 and $1.14 \mathrm{mg} \mathrm{cm}^{-3}$ contents were shown for both coffee species (Maeztu et al. 2001) but similar values were obtained only in Arabica coffee beverages obtained from beans roasted at $220 \pm 10^{\circ} \mathrm{C}$ for $9 \mathrm{~min}$. The different patterns obtained for Arabica and Robusta beverages probably are linked to the different diffusion coefficients of caffeine, this being the result of the physical structure and particle size of the beans (Saldaña et al. 1997; Andueza et al. 2003) and to physical-chemical characteristics of each grain specie (Toci et al. 2006). In addition, these trends can further be linked to the chemical composition of the cell wall that also can influence the phenomenon of partition of different compounds during their extraction (Fischer et al. 2001).

The contents of 3-CQA, 4-CQA, 5-CQA and total caffeoylquinic acids ( $\left.\operatorname{diCQA}_{\text {total }}\right)$ in Arabica and Robusta coffee beverages also decreased with the intensity of roasting, but were not significantly different for the same degree of browning (Table II). As previously reported by Fujioka and Shibamoto (2008), isomer 5-CQA was quantitatively the most important in Arabica and Robusta beverages, followed by 4-CQA and 3-CQA (Table II). The levels of 3,4diCQA, 3,5-diCQA, 4,5-diCQA and total fatty dicaffeoylquinic acids $\left(\right.$ diCQA $\left._{\text {total }}\right)$ also decreased with increasing roasting intensity and remained significantly higher in Robusta coffee drinks for similar levels of roasting (Table III). The levels of 3,4-diCQA were also higher than those of 3,5-diCQA and 4,5diCQA (Table III), therefore, following a pattern also shown by Fujioka and Shibamoto (2008). The levels of 3-FQA, 5-FQA and total fatty feruolilquínic acids $\left(\mathrm{FQA}_{\text {total }}\right)$ sharply decreased with increasing roasting, but remained significantly higher in Robusta coffee for the same browning degree (Table IV). Overall, the content of total chlorogenic acids was significantly higher in Robusta coffee beverages due to the higher levels of diCQA $A_{\text {total }}$ (Tables II-IV). The percentage ratio of 5-CQA and diCQA $A_{\text {total }}$ also remained at higher levels in Arabica coffee beverages in all roasting intensities, unlike the percentage ratio of $\mathrm{FQA}_{\text {total }}$ and diCQA $_{\text {total }}$, which showed a higher value in Robusta coffee drinks (Tables II-IV). The percentage ratio of diCQA total $_{\text {markedly decreased in Arabica and }}$ Robusta beverages, therefore, following an antagonistic pattern relative to the ratio and percentage of diCQA $_{\text {total }}$ and $\mathrm{FQA}_{\text {total }}$ (Tables II-IV). Thus, the relative importance of $\mathrm{FQA}_{\text {total }}$ for diCQA $\mathrm{A}_{\text {total }}$

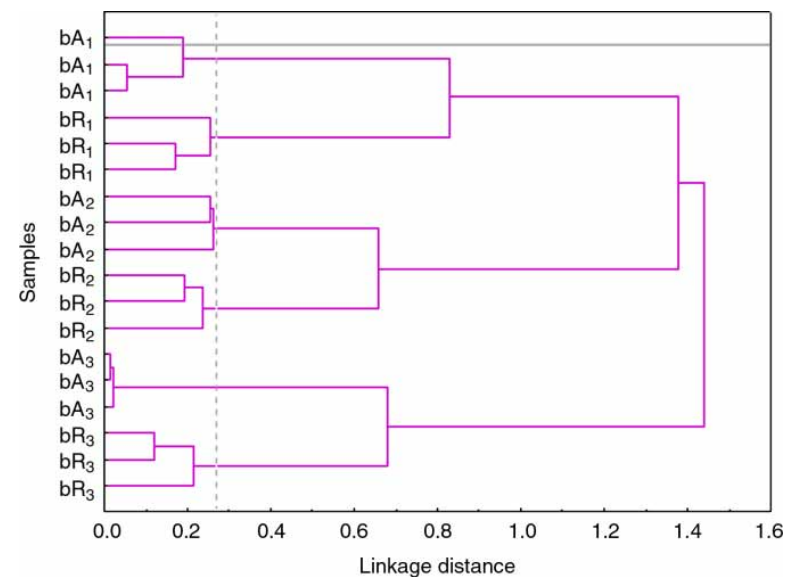

Figure 3. On the basis of Euclidean distances, dendrogram of coffee samples, considering $\mathrm{pH}$, caffeine, trigonelline, diCQA $\mathrm{A}_{\text {total }}$, $\operatorname{diCQA}_{\text {total }}$ and $\mathrm{FQA}_{\text {total }}$ between them. The symbols have the following meaning: $b=$ beverage; $A_{1}, A_{2}, A_{3}$ and $R_{1}, R_{2}$, $R_{3}=$ roasting of Arabica and Robusta green beans at $220 \pm 10^{\circ} \mathrm{C}$, for 7, 9 and $11 \mathrm{~min}$, respectively. 
Table VI. Correlation coefficients between the first and second principal components $\left(\mathrm{CP}_{1}\right.$ and $\left.\mathrm{CP}_{2}\right)$ with 3-CQA, 4-CQA, 5-CQA, 3,4-diCQA, 3,5-diCQA, 4,5-diCQA, 3-FQA and 5-FQA.

\begin{tabular}{lcc}
\hline Variables & $\mathrm{CP}_{1}$ & $\mathrm{CP}_{2}$ \\
\hline 3-CQA & -0.953 & -0.301 \\
4-CQA & -0.945 & -0.314 \\
5-CQA & -0.924 & -0.382 \\
3,4-diCQA & -0.970 & 0.112 \\
3,5-diCQA & -0.992 & 0.072 \\
4,5-diCQA & -0.992 & 0.018 \\
3-FQA & -0.878 & 0.465 \\
5-FQA & -0.932 & 0.354 \\
Eigenvalue & 7.20 & 0.69 \\
Variance (\%) & 90.05 & 8.67 \\
\hline
\end{tabular}

increased in drinks prepared with more intense roasted coffee.

Equating the concentration of caffeine, trigonelline, soluble solids, $\mathrm{pH}, \operatorname{diCQA}_{\text {total }}, \operatorname{diCQA}_{\text {total }}$ and $\mathrm{FQA}_{\text {total }}$, three principal components were defined in the coffee beverages, comprising $96.6 \%$ of the total variance $\left(\right.$ Table $\mathrm{V}$ ). The levels of $\operatorname{diCQA}_{\text {total }}$, diCQA $_{\text {total, }}$ trigonelline and $\mathrm{FQA}_{\text {total }}$ significantly correlated with the first principal component (Table V; Figure 1), being higher in lower roasted coffee drinks. Therefore, the first principal component detached the beverages according to coffee roasting intensity. Caffeine and $\mathrm{pH}$ were identified as variables of the second principal component (Table V; Figure 1), allowing the separation of drinks according to the species, and rising higher for drinks of Robusta coffee. To explain the variation among the coffee samples, the third principal component had a minor importance. Moreover, the content of soluble solids correlated with this component, allowing the separation Arabica and Robusta coffee drinks having the same degree of roasting (Table V; Figure 1). Although these variables were important as chemical descriptors, the most relevant were $\operatorname{diCQA} A_{\text {total }}, \operatorname{diCQA}_{\text {total }}$ and caffeine.

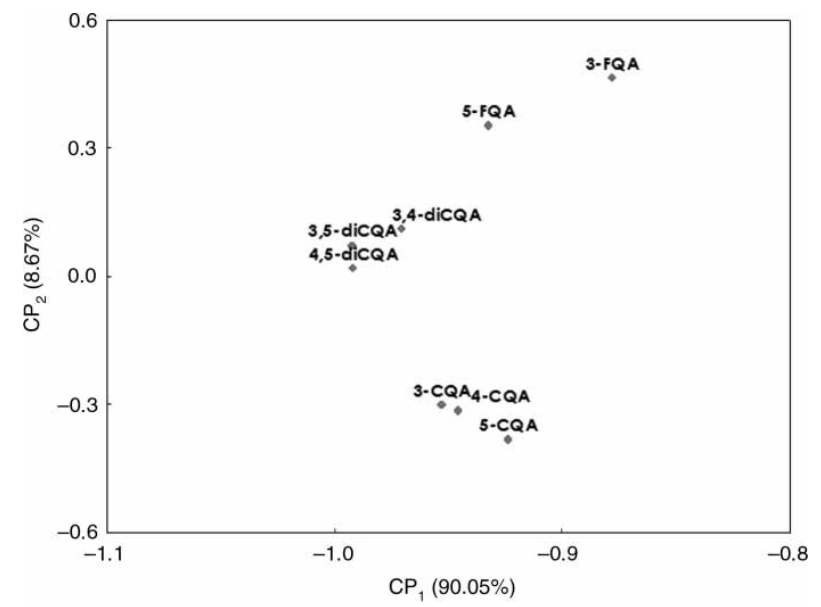

Figure 4. Projection of 3-CQA, 4-CQA, 5-CQA, 3,4-diCQA, 3,5diCQA, 4,5-diCQA, 3-FQA and 5-FQA plans designed by the first and second principal components $\left(\mathrm{CP}_{1}\right.$ and $\left.\mathrm{CP}_{2}\right)$.

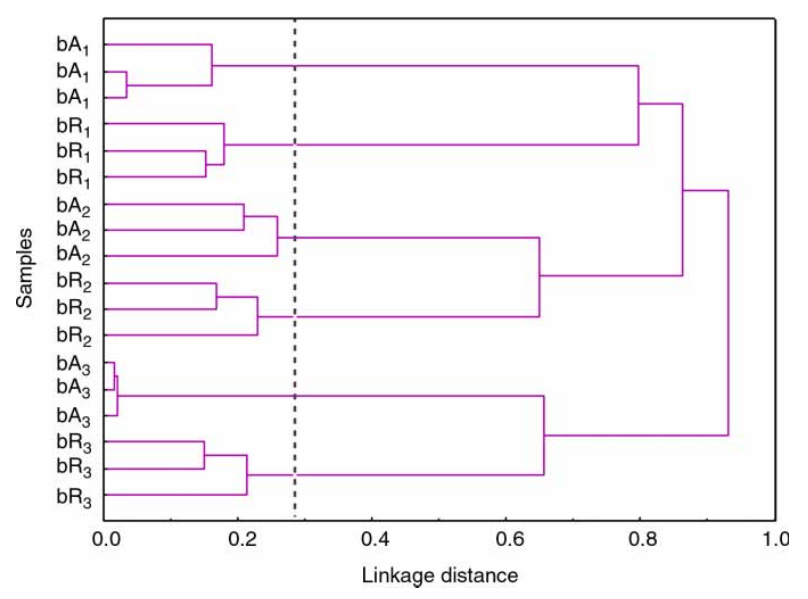

Figure 5. Dendrogram of samples beverages based on Euclidean distances, considering the variables $\mathrm{pH}$, caffeine, trigonelline, 3-CQA，4-CQA，5-CQA，3,4-diCQA，3,5-diCQA，4,5-diCQA, 3-FQA and 5-FQA. The symbols have the following meaning: $\mathrm{b}=$ beverage; $\mathrm{A}_{1}, \mathrm{~A}_{2}, \mathrm{~A}_{3}$ and $\mathrm{R}_{1}, \mathrm{R}_{2}, \mathrm{R}_{3}=$ roasting of Arabica and Robusta green beans at $220 \pm 10^{\circ} \mathrm{C}$, for 7,9 and $11 \mathrm{~min}$, respectively.

Consequently, the coffee drinks parameters formed six groups (Figure 2). The soluble solids content persisted with lower importance to explain the variance among samples of coffee drinks. The remaining parameters $\left(\mathrm{pH}\right.$, caffeine, trigonelline, diCQA $\mathrm{A}_{\text {total }}, \mathrm{diCQA}_{\text {total }}$ and $\left.\mathrm{FQA}_{\text {total }}\right)$ enabled by itself a discrimination between samples, as was further seen through its hierarchical classification for a distance connection around 0.3 (Figure 3). The total content of each group of chlorogenic acids was relevant for the separation of beverages (Table VI; Figure 4). The analysis of the principal components showed that all the individual groups of total chlorogenic acids (3-CQA, 4-CQA, 5-CQA, 3,4-diCQA, 3,5-diCQA, 4,5-diCQA, 3-FQA and $5-\mathrm{FQA}$ ) could explain $90 \%$ of the variance among samples of coffee drinks (Table VI; Figure 4). Thus, the individual groups of chlorogenic acids in the coffee drinks are highly correlated with the first principal component, which may constitute an axis for samples separation by the roasting degree. In general, the individual fractions are highly correlated with the first principal component, whereas the fraction 3-FQA becomes less important although significant. Considering the patterns of 3-CQA, 4-CQA, 5-CQA, 3,4diCQA, 3,4-diCQA, 4,5-diCQA, 3-FQA and 5-FQA, as well as the other parameters (caffeine, trigonelline and $\mathrm{pH}$ ), and since the soluble solids have not proved to be a good discriminator, again it is concluded that the coffee drinks parameters might constitute six individual groups (Figure 5).

\section{Conclusion}

The chemical composition of the beverages of Arabica and Robusta coffee beans from Brazil and India subjected to increasing roasting intensity might vary at 
different levels. Total soluble solids and $\mathrm{pH}$ had lower values when beans are roasted at $220 \pm 10^{\circ} \mathrm{C}$, for $9 \mathrm{~min}$. The contents of caffeine did not vary significantly but trigonelline and chlorogenic acids sharply decreased with higher burning up. Considering all the patterns of these variables, the beverages can therefore be discriminated following the intensity of coffee roasting, the kind of coffee and, under the same degree of roasting, the coffee type.

Declaration of interest: The authors wish to thank Dr Joel I. Fahl and Dr Maria Luíza Carelli (IAC) for the supply of seed material. The authors report no conflicts of interest. The authors alone are responsible for the contents and writing of the paper.

\section{References}

ABIC. 2007. Revision 15. Quality standard and recommended practices of manufacturing roasted coffee beans and ground roasted coffee. Rio de Janeiro, Brazil: Brazilian Association of Coffee. p 1-20.

Alvarenga NBMG. 2009. Studies in texture of cheeses of Serpa. Lisbon, Portugal: Instituto Superior de Agronomia, Technical University of Lisbon. p 1-93.

Andueza S, Peña MP, Cid C. 2003. Chemical and sensorial characteristics of espresso coffee as affected by grinding and torrefacto roast. J Agric Food Chem 51:7034-7039.

AOAC. 1996a. Coffee and tea. AOAC International - Association of Official Analytical Chemists, volume 2, chapter 30, Madison, Wisconsin, USA.

AOAC. 1996b. Definition of terms and explanatory notes. AOAC International - Official methods of analysis, volume 1, note 11 , Madison, Wisconsin, USA.

Bell LN, Wetzel CR, Grand AN. 1997. Caffeine content in coffee as influenced by grinding and brewing techniques. Food Res Intern 29:785-789.

Bicho NCC. 2005. Food quality and safety in green coffee and acclimation of the genus Coffee in conditions of environmental stress. Caparica, Portugal: Faculty of Science and Technology, New University of Lisbon. p 1-232.

Bicho NCC. 2009. Study of some chromatic parameters, sensory, technological and chemical properties of the coffee bean. Caparica, Portugal: Faculty of Science and Technology, New University of Lisbon. p 1-299.

Bicho NCC, Letão AE, Ramalho JC, Alvarenga NB, Lidon FC. 2011. Identification of chemical clusters discriminators of Arabica and Robusta green coffee. Int J Food Prop, in press.

Blitz HB, Grocsh W. 1988. Food chemistry. Zaragoza, Espanha: Editorial Acribia, S.A., 1-6; p 747-760.

Chapman KW, Lawless HT, Boor KJ. 2001. Quantitative descriptive analysis and principal component analysis for sensory characterization of ultrapasteurized milk. J Dairy Sci 84:12-20.

Clifford MN. 1987. Chemical and physical aspects of green coffee products. In: Clifford MN, Wilson KC, editors. Coffee, botany, biochemistry and production of beans and beverage. New York: Croom Helm \& Methuen Inc., EUA. p 305-374.

Clifford MN. 1989. Chlorogenic acids. In: Clarke RJ, Macrae R, editors. Coffee, I: chemistry. London and New York: Elsevier Applied Science Publishers Co., Ltd. p 153-202.

Clifford MN. 1999. Chlorogenic acids and other cinnamates nature, occurrence and dietary burden. J Sci Food Agric 79:362-372.
Correia MNG. 1990. Influência da torra na evolução dos ácidos clorogénicos do café. Lisboa: Instituto Superior de Agronomia, Universidade Técnica de Lisboa.

Correia MNG. 1995. Handbook of coffee technology. Cultivar. Porto, Portugal: Technical Association of Tropical Crops.

Da Silva AFS, Minim VPR, Chaves JBP, Stringheta PC, Ribeiro MM. 2004. Evaluation of the bitter taste of the drink coffee (Coffea arabica L.) by analyzing organic intensity time. Food Science Technology 24:468-472.

Farah A, De Paulis T, Trugo LC, Martin PR. 2005. Effect of roasting on the formation of chlorogenic acid lactones in coffee. J Agric Food Chem 53:1505-1513.

Fischer M, Reimann S, Trovatto V, Redgwell RJ. 2001. Polysaccharides of green Arabica and Robusta coffee beans. Carbohydr Res 330:93-101.

Fujioka K, Shibamoto T. 2008. Chlorogenic acid and caffeine contents in various commercial brewed coffees. Food Chem 1: $217-221$.

Illy A, Viani R, editors. 1998. Espresso coffee: the chemistry of quality. 3rd ed., London: Academic Press Limited. p 1-253.

ISO 10095. 1992. Coffee - determination of caffeine content method using high-performance liquid chromatography. Geneva, Switzerland: International Organization for Standardization.

ISO 4072. 1982. Green coffee in bags - sampling. Geneva, Switzerland: International Organization for Standardization.

ISO 6668. 1991. Green coffee. Preparation of samples for use in sensory analysis. Geneva, Switzerland: International Organization for Standardization.

Lingle TR. 1996. The coffee brewing handbook: a systematic guide to coffee preparation. Long Beach, CA, USA: Speciality Coffee Association of America. p 1-59.

Maeztu L, Andueza S, Ibañez C, de Peña MP, Bello J, Cid C. 2001. A multivariate method for differentiation of espresso from botanical varieties and types of roast by foam, taste and mouthfeel characteristics. J Agric Food Chem 49:4743-4747.

Mendonça LMVL, Pereira RGFA, Mendes ANG. 2005. Parâmetros bromatológicos de grãos crus e torrados de cultivares de café (Coffea arabica L.). Ciênias Tecnologia Alimentar 25: $239-243$.

Nestlé. 1991. Coffee. Vevey, Switzerland: Documentation Centre, Corporate Affairs Department, Nestec Ltd. p 1-60.

Neto JMM, Moita GC. 1998. Uma introdução à análise exploratória de dados multivariados. Química Nova 21:467-469.

Normative Instruçãoo $\mathrm{N}^{\circ}$ 8. 2003. Regulation and identity of technical quality standards for the classification of raw green coffee beans. Brazil: Ministry of State for Agriculture, Livestock and Supply.

NP 1666. 1980. Coffee-Sampling of green coffee in bags. Lisbon, Portugal: Directorate General of Quality.

PSCB $N^{\circ}$ 36/02. 2002. Code of practice: enhancement of coffee quality through prevention of mould formation. Netherlands: International Coffee Organization.

Saldaña MDA, Mazzafera P, Mohamed RS. 1997. Extracção dos alcalóides cafeína e trigonelina dos grãos de café com $\mathrm{CO}_{2}$ supercrítico. Ciências Tecnologicas Alimentares 17:371-376.

Smith AW. 1989. Introduction. In: Clarke RJ, Macrae R, editors. Coffee, I: chemistry. London \& New York: Elsevier Applied Science Publishers Co., Ltd. p 1-41.

Toci A, Farah A, Trugo LC. 2006. Efeito do processo de descafeinação com diclorometano sobre a composição química dos cafés Arabica e Robusta antes e após a torração. Química Nova 29:965-971.

Viani R. 1993. The composition of coffee. In: Garatin S, editor. Caffeine, coffee, and health. New York: Raven Press, Ltd. p $17-41$. 